\title{
ANALISIS EJEKSI DAN DISPERSI AWAN DEBU VULKANIK GUNUNG SEMERU JAWA TIMUR
}

\author{
Oleh: \\ Agus Krisbiantoro ${ }^{1}$
}

\begin{abstract}
ABSTRAK: Volcanic Ash Clouds atau awan debu vulkanik merupakan salah satu aktivitas yang ditunjukkan oleh gunungapi. Karakterisasi awan debu vulkanik suatu gunung api merupakan upaya monitoring aktivitas suatu gunung api. Monitoring aktivitas gunung api merupakan bagian dari penanggulangan dan kesiapsiagaan terhadap bencana atau bahaya yang diakibatkan oleh aktivitas gunungapi. Gunung Semeru sebagai gunungapi teraktif di Indonesia secara periodik mengeluarkan atau mengejeksikan material debu vulkanik ke atmosfer yang membentuk awan vulkanik. Dampak yang ditimbulkan oleh awan debu vulkanik Gunung Semeru tidak hanya mengancam kehidupan manusia tetapi juga mengancam sumber kehidupan manusia. Teknologi penginderaan jauh atau remote sensing digunakan untuk mengidentifikasi karateristik spketral awan debu vulkanik Gunung Semeru. Data yang digunakan dalam penelitian ini meliputi Citra Satelit Landsat TM perekaman tahun 2001 sampai dengan 2010 dan Data Lidar Satelit CALIPSO.
\end{abstract}

Kata Kunci: Awan debu vulkanik, Mitigasi, Remote Sensing, Citra Satelit

\section{PENDAHULUAN}

Identifikasi aktivitas suatu gunungapi merupakan hal yang mutlak untuk dilakukan dalam rangka mengetahui karakteristik gunungapi. Pemahaman tentang karakteristik gunung api merupakan investasi dan tindakan aktif yang diperlukan sebagai upaya penanggulangan dan kesiapsiagaan terhadap bencana atau bahaya yang diakibatkan. Gunung Semeru sebagai salah satu gunungapi teraktif di Indonesia menunjukkan aktivitas letusan secara periodik yang menghasilkan awan debu vulkanik. Perhatian utama mitigasi bencana dan ancaman Gunung Semeru selama ini antara lain bencana aliran lava pijar, aliran awan panas dan lahar dingin yang berupa banjir yang membawa material vulkanik. Sedangkan bahaya dan ancaman yang ditimbulkan oleh awan debu vulkanik belum menjadi bagian dalam mitigasi.

Awan debu vulkanik merupakan material debu vulkanik yang diejeksikan ke atmosfer menyerupai bentuk kolom jamur/cendawan membumbung vertikal yang dapat diamati secara visual, kemudian terdispersi mengikuti arah angin.[3]. Dampak yang ditimbulkan oleh awan debu vulkanik bisa secara langsung maupun tidak langsung terhadap kehidupan manusia.[7]. Material debu vulkanik merupakan materil pyroclastic berukuran antara 0,3 sampai 30 mikron, apabila terdispersi dan terhirup oleh manusia

\footnotetext{
${ }^{1}$ Jurusan Fisika Pascasarjana Universitas Brawijaya Malangd with
} 
maka akan menyebabkan gangguan pada saluran pernafasan dan bisa menyebabkan iritasi serta dapat pula berdampak pada lingkungan.[1]

Untuk menganilasis karakteristik awan debu vulkanik Gunung Semeru digunakan teknologi remote sensing.[4][5]. Teknologi remote sensing sebagai teknologi pengukuran jarak jauh yang mempunyai kapasitas keruangan atau spatial yang cukup luas dan kapasitas temporal yang mampu merekam secara periodik dinamika awan debu vulkanik di atmosfer. Sudut pandang penginderaan jauh, setiap objek di permukaan bumi akan memiliki karakteristik spektral elektromagnetik tertentu yang beda antara satu objek dengan objek yang lain. Gambar 1 menunjukkan bahwa debu vulkanik mempunyai indeks refraksi atau karakteristik spektral yang berbeda dengan material yang lain dalam hal ini awan es dan cairan air awan. Perbedaan indeks tersebut sebagai prinsip dasar dalam membedakan partikel vulkanik dengan partikel yang lain ketika debu vulkanik yang terdistribusi di atmosfer. [6]

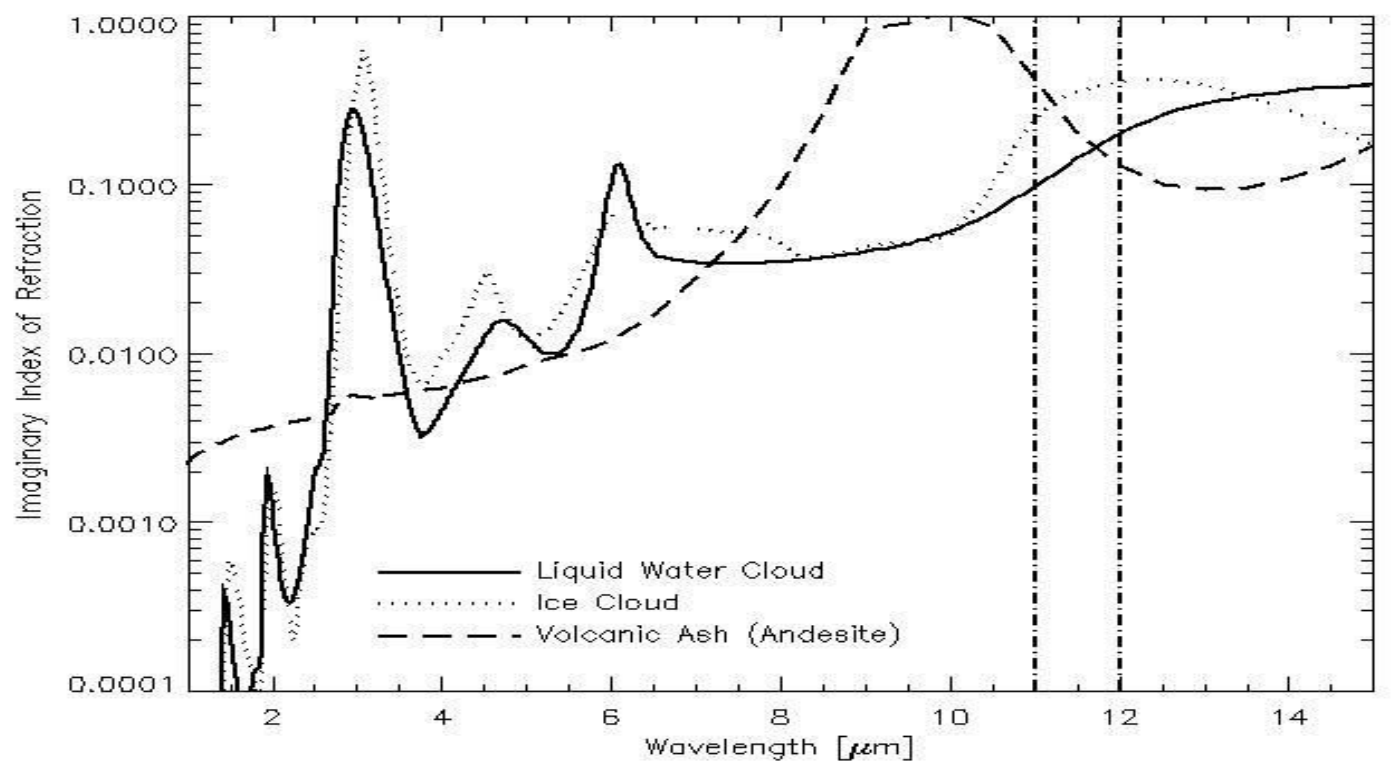

Gambar 1. Indeks refraksi debu vulkanik (volcanic ash andesite) dibandingkan dengan cairan air awan dan awan es

Dalam menunjang hasil analisis karateristik awan debu vulkanik Gunung Semeru tersebut, dilakukan simulasi dispersi pada kejadian atau event erupsi. Akusisi data pengindearaan jauh menggunakan citra satelit Landsat dan data satalit CALIPSO[2]. Akusisi data simulasi meliputi : waktu terjadinya erupsi ejeksi awan debu vulkanik, durasi, warna awan debu vulkanik, arah, dan tipe dispersi.[6]

\section{METODE PENELITIAN}

Awan vulkanik akan terdispersi pada arah atau wilayah tertentu mengikuti arah angin. Sebaran dispersi debu vulkanik tersebut diidentifikasi melalui visual citra satelit 
(Calipso, Landsat TM) dengan pengolahan citra digital ER-Mapper. Untuk mendapatkan gambaran dispersi secara lebih lengkap pada visual citra satelit tersebut akan direkontruksi dengan melakukan simulasi atau pemodelan dispersi debu vulkanik dengan menggunakan data arsip pada situs http:// ready.arl.noaa.gov/hysplit.php, yang merekam data cuaca pada waktu yang lalu pada saat terjadi erupsi Gunung Semeru.

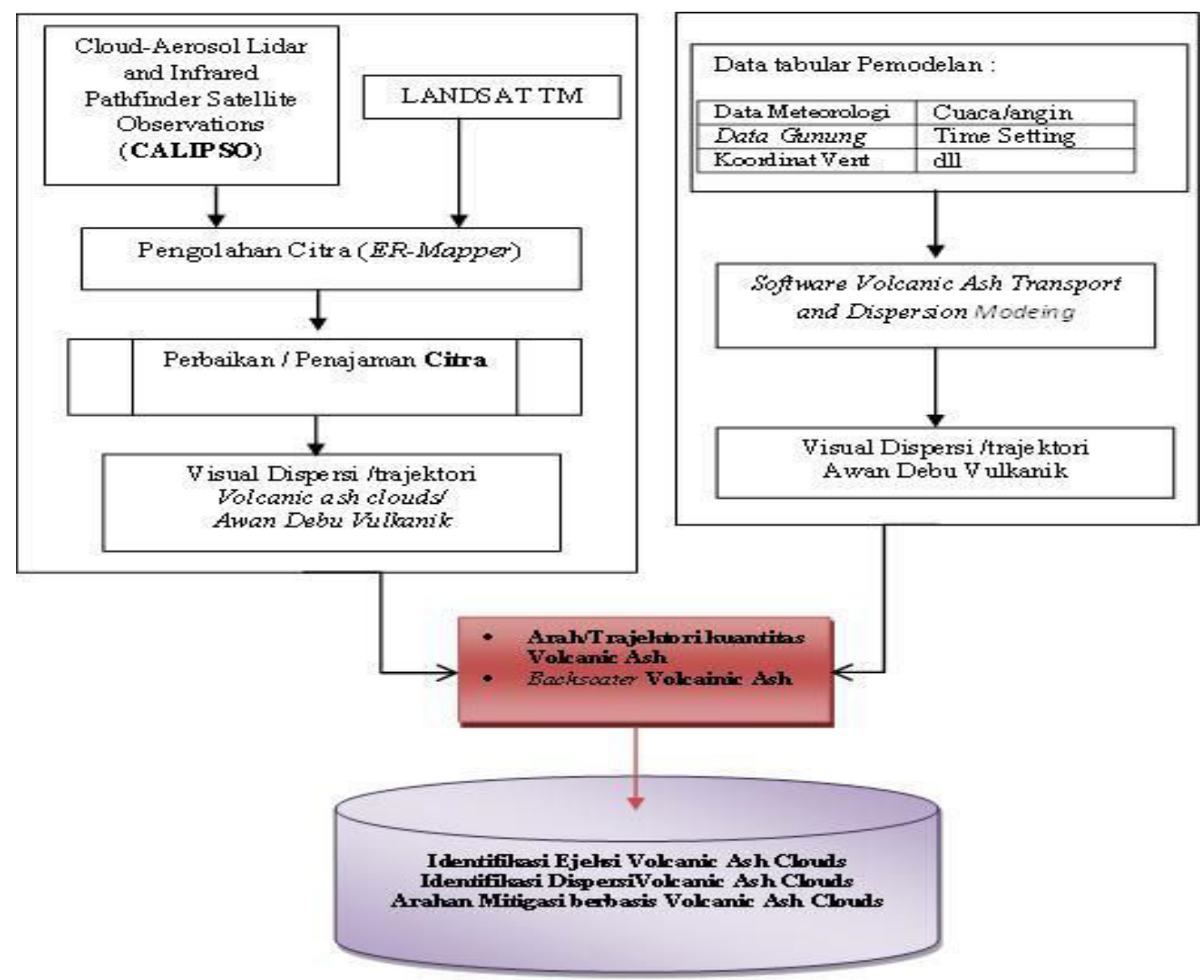

Gambar 2. Diagram alir penelitian

Kuantitas spasial data citra satelit akan memberikan informasi tentang kenampakan fisis visual awan debu vulkanik dan memberikan gambaran atau grafik spektralnya serta memberikan informasi yang lebih penting berupa konsentrasi partikel - partikel yang terdispersi (scene depth of volcanic ash clouds atau vertical profile). Data spasial citra satelit CALIPSO digunakan untuk menganalisa kuantitas awan debu vulkanik secara vertikal dan Citra Landsat TM untuk mengetahui kuantitas awan debu vulkanik secara lateral.

\section{HASIL PENELITIAN}

Perekaman data citra Satelit Landsat TM dan Satelit CALIPSO didasarkan rekapitulasi data kejadian erupsi Gunung Semeru yang bersumber dari Pusat Vulkanologi 
dan Mitigasi Bencana Geologi - Indonesia (PVMBG) dan Volcanic Ash Advisory Center - Darwin Australia (VAAC).

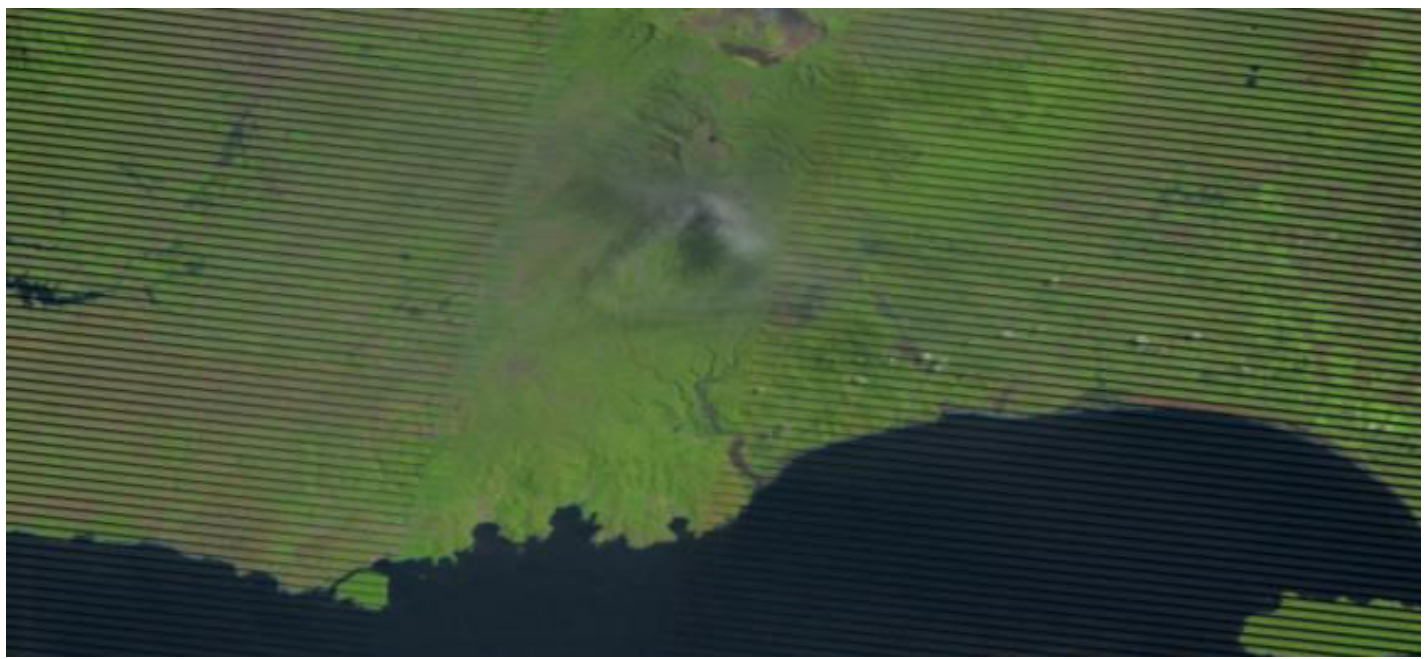

Gambar 3. Dispersi awan debu vulkanik Citra Landsat TM perekaman 25 Juni 2006

Gambar 3 merupakan dispersi awan debu vulkanik erupsi Gunung Semeru pada tanggal 25 Juni 2006 yang terekam oleh Satelit Landsat TM. Gambar 3 menunjukkan awan debu vulkanik diejeksikan ke atmosfer dan terdispersi ke arah selatan dan barat daya. Sedangkan Gambar 4 menunjukkan visual secara vertikal awan debu vulkanik erupsi Gunung Semeru pada tanggal 25 Juni 2006, terlihat bahwa pada koordinat antara Lat -11.71, Lon 112.09 sampai dengan Lat -5.60, Lon 110.47 menunjukkan peningkatan bondary layer. Peningkatan bondary layer mengindikasikan kuantitas awan debu vulkanik Gunung Semeru yang diejeksikan ke atmosfer (lingkaran merah) pada ketinggian antara 4 Km sampai $10 \mathrm{Km}$

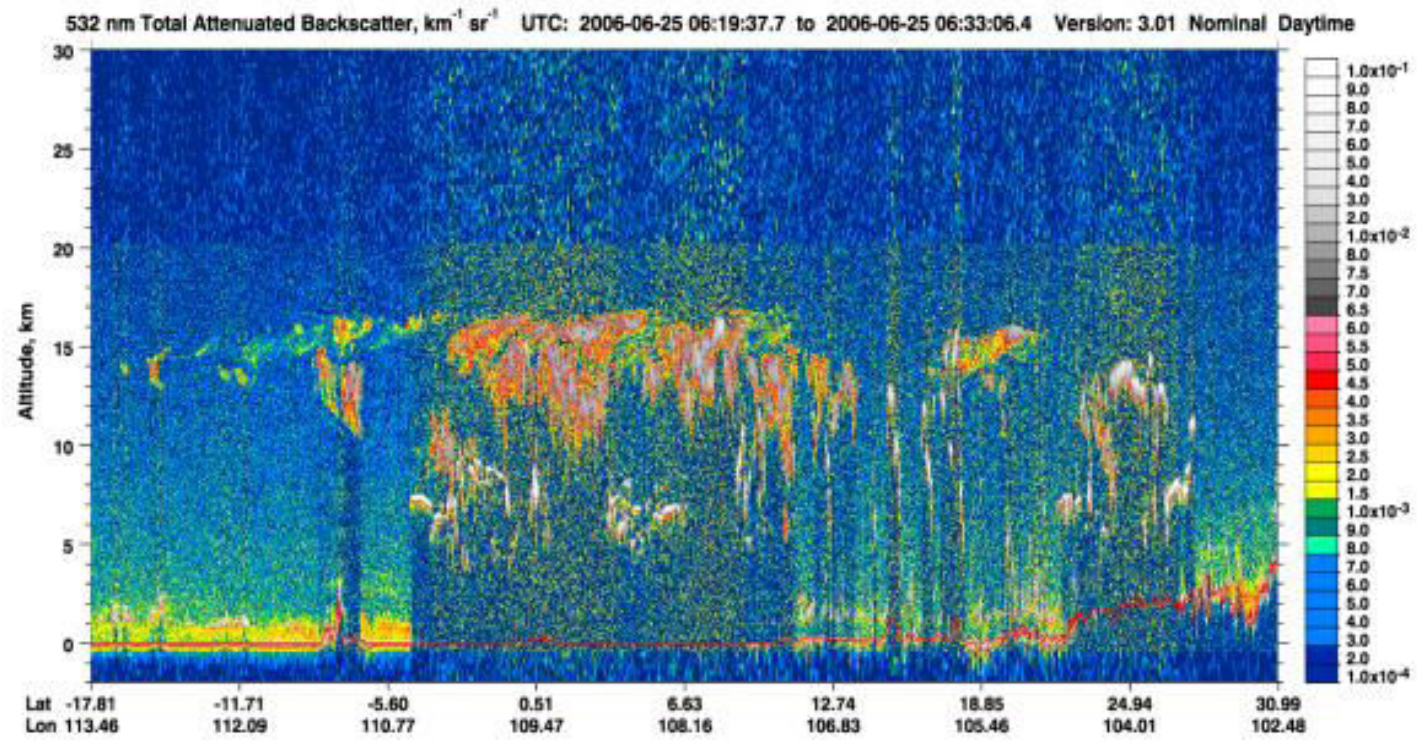

Gambar 4. Kuantitas aerosol berupa awan debu vulkanik yang diejeksikan Gunung Semeru perekaman data Lidar Satelit CALIPSO perekaman 25 Juni 2006 


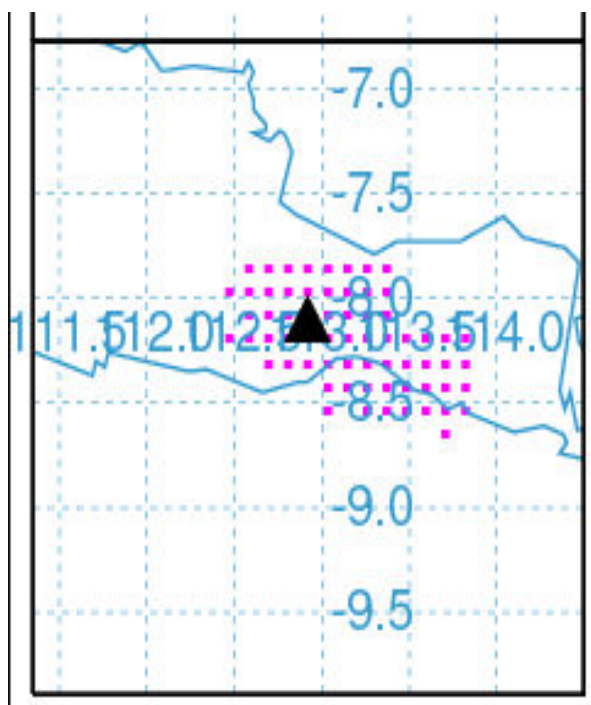

VALID $0600 Z 25$ JUN 06 (ERUPTION+006H00M)

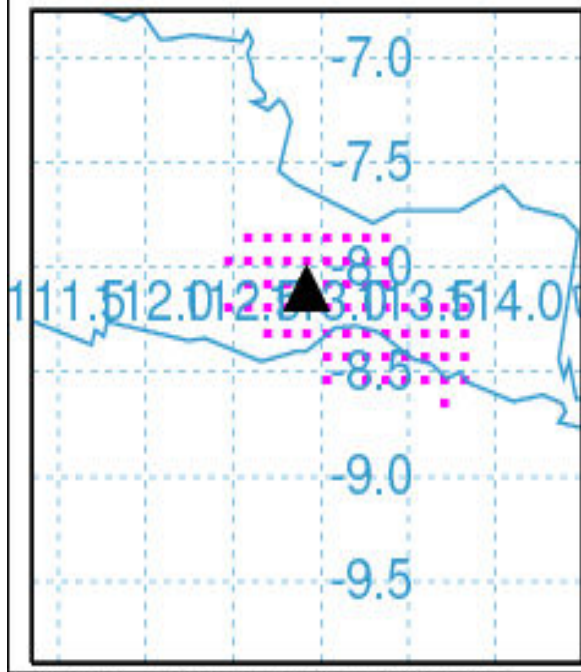

NOAA HYSPLIT GUIDANCE

A SEMERU SO806E11255

SUMMIT $12057 \mathrm{FT}$

ERUPTION 0000Z 25 JUN 06

DURATION $1 \mathrm{HR}$

ASH COLUMN FL180

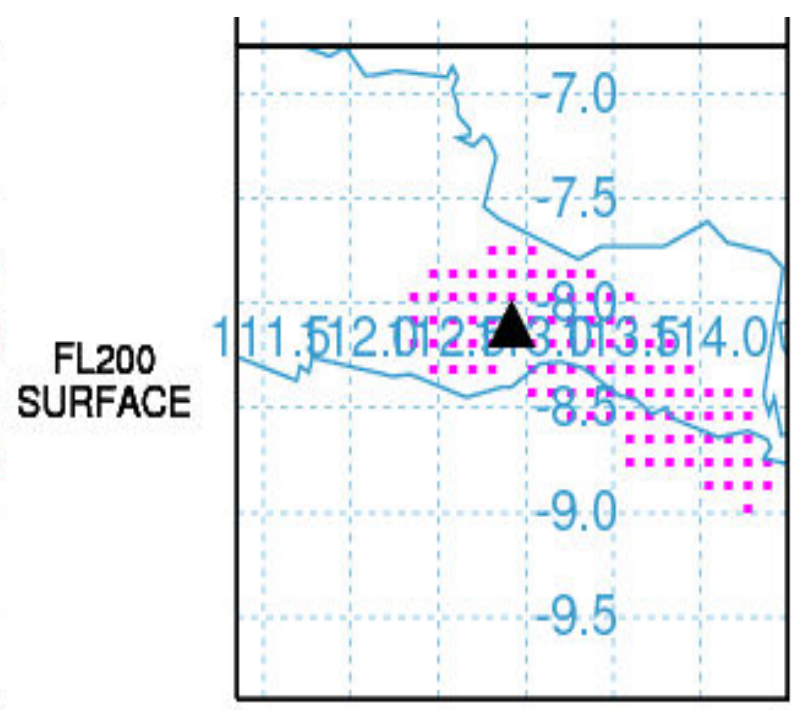

VALID $1200 Z 25$ JUN 06 (ERUPTION+012H00M)
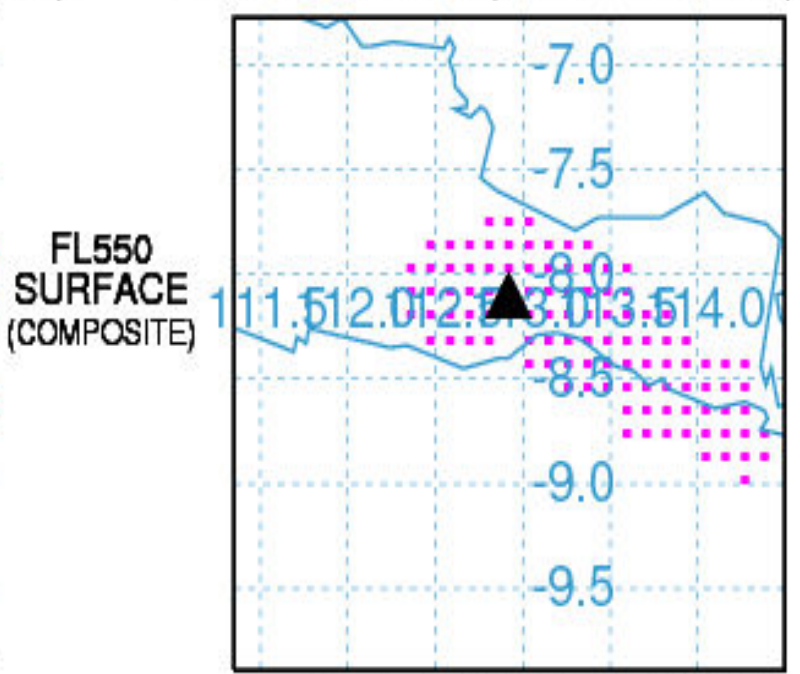

Created: 0032 GMT 20110924

GDAS CYCLE

06Z 25 JUN 06
VISUAL ASH CLOUD

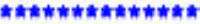

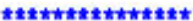

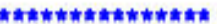

Job ID: 44107

Gambar 5. Simulasi ejeksi dan dispersi erupsi Gunung Semeru pada 25 juni 2006

Gambar 5 merupakan hasil rekontruksi simulasi dispersi awan debu vulkanik Gunung Semeru pada tanggal 25 Juni 2006, terlihat bahwa dispersi awan debu vulkanik bergerak ke selatan dan barat daya Gunung Semeru. Sedangkan pada Gambar 6 mensimulasikan trajektori awan debu vulkanik secara vertikal. Terlihat bahwa awan debu vulkanik diejksikan pada ketinggian antara $4200 \mathrm{~m}$ sampai dengan $6000 \mathrm{~m}$ dari permukaan laut. 


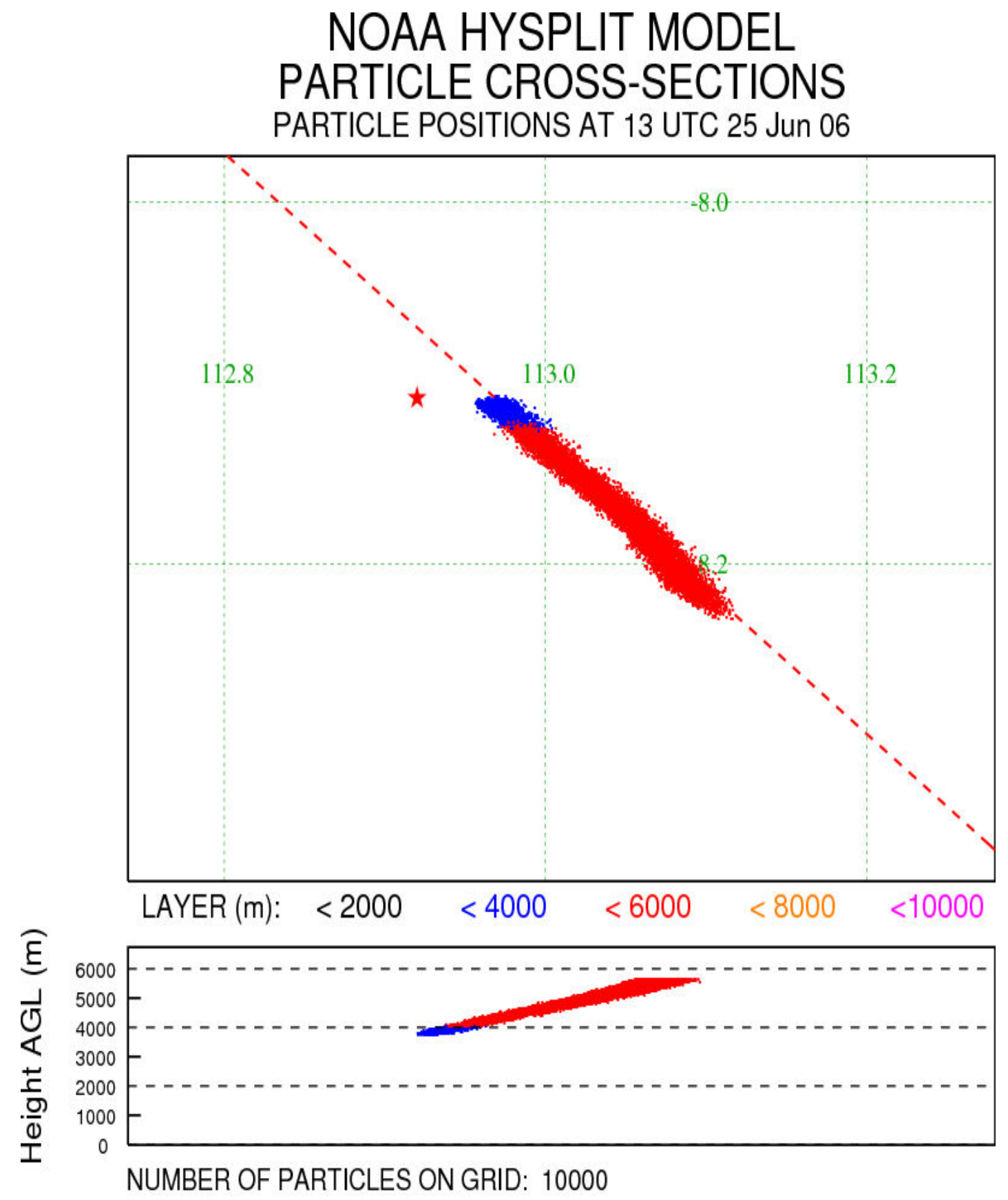

Gambar 6. Visual Vertikal kuantitas awan debu vulkanik Gunung Semeru di atmosfer pada 25 Juni 2006

Dispersi awan debu vulkanik Gunung Semeru dapat dibedakan menjadi tiga tipe yaitu : Fan Type, Belt type dan Linear Type.

- Fan Type adalah Bentuk dispersi awan debu vulkanik yang terjadi ketika angin dibagian bawah lemah tetapi pergeseran secara vertikal besar atau kuat, sehingga 
menyerupai bentuk fan atau kipas yang berputar atau membentuk pusaran/putaran kearah vertikal.

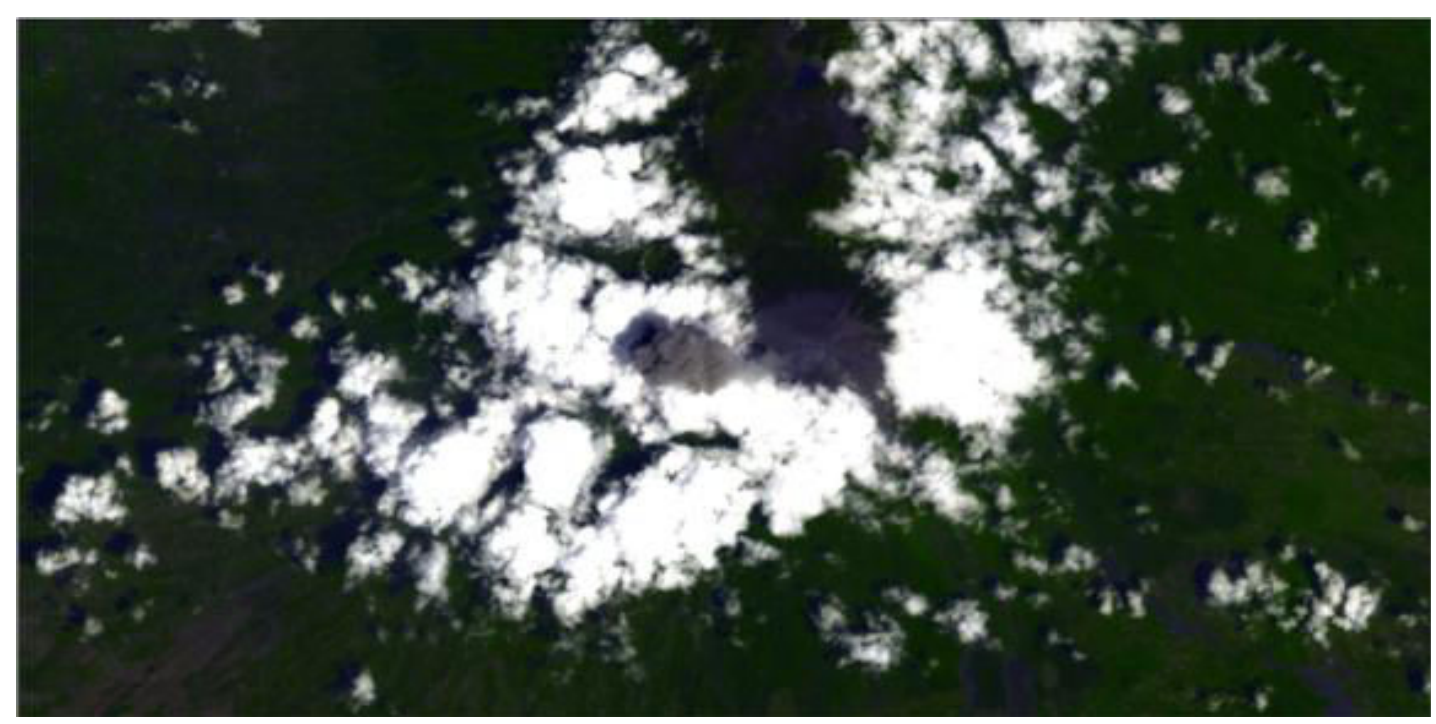

Gambar 7. Dispersi awan debu vulkanik Tipe Fan

- Belt Type adalah bentuk dispersi awan debu vulkanik yang terjadi ketika angin tidak muncul secara signifikan, tetapi dispersi menampakkan pergerakan pada arah yang kecil. Bentuk dispersi tipe ini lebih bebas atau pada umumnya tidak beraturan.

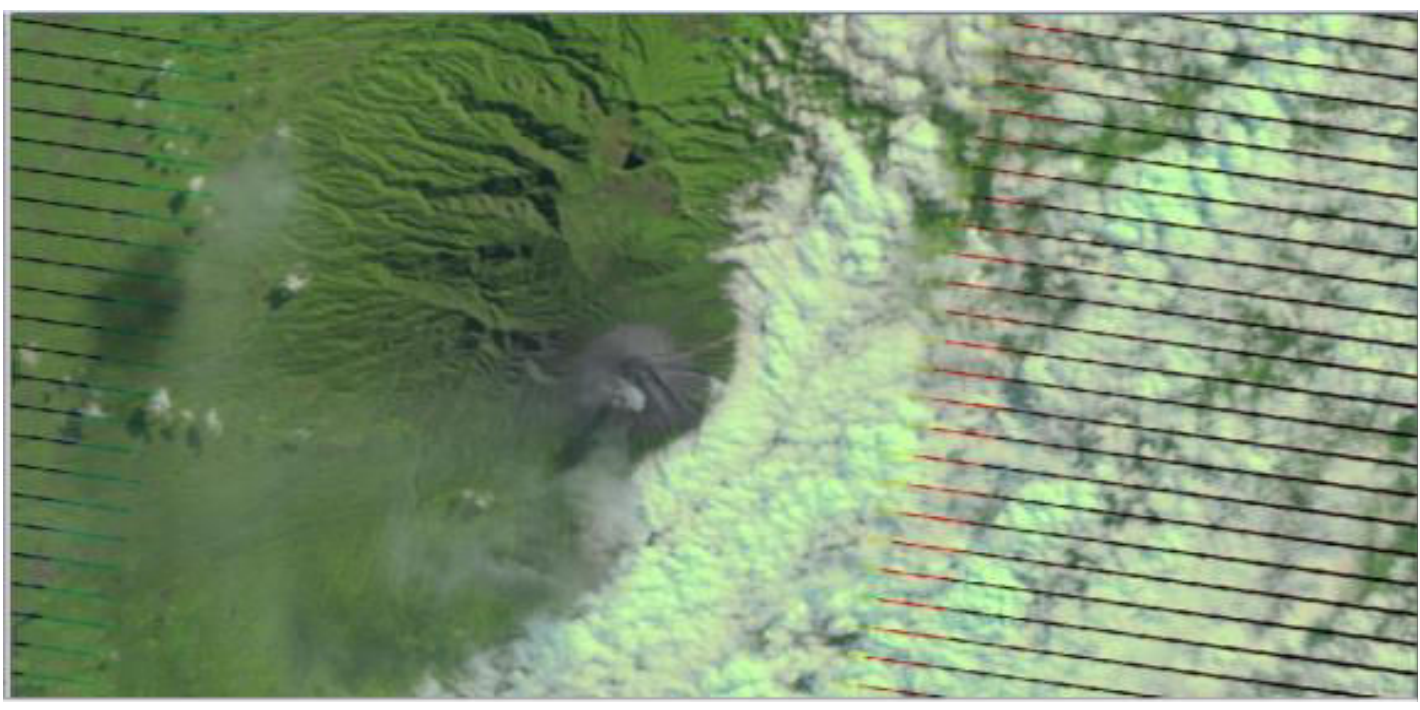

Gambar 8. Dispersi awan debu vulkanik Tipe Belt

- Linear Type adalah Bentuk dispersi awan debu vulkanik yang terjadi ketika awan debu vulkanik sejajar dengan angin diatas atmosfer sedangkan dibagian bawah kolom angin tidak signifikan, dimana bentuk awan debu vulkanik mengalami dispersi yang sejajar atau searah dalam arah garis lurus. 


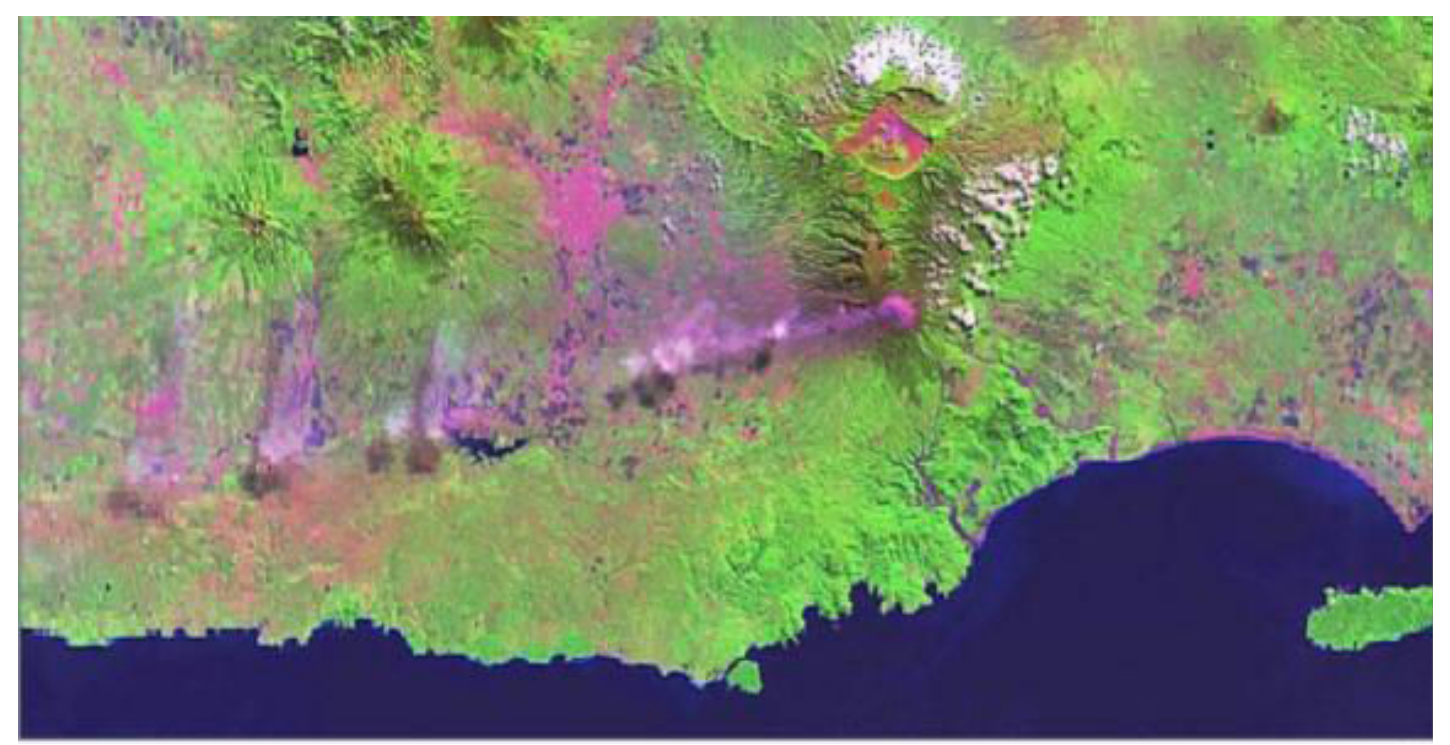

Gambar 9. Dispersi awan debu vulkanik Tipe Linear

Rekapitulasi hasil pengolahan dan analisis data citra satelit dan simulasi dispersi awan debu vulkanik Gunung Semeru ditunjukkan Tabel 1. Pada tabel tersebut terlihat bahwa dispersi baik hasil pengolahan data citra maupun data hasil simulasi menunjukkan bentuk atau pattern yang relatif sama. Karakteristik bentuk dispersi hasil ejeksi Gunung Semeru memberikan arahan berupa bentuk dan arah serta jarak. Karakteristik dispersi tersebut digunakan sebagai arahan mitigasi bencana atau dampak yang ditimbulkan awan debu vulkanik Gunung Semeru.

Tabel 1. Perbandingan arah dispersi antara citra satelit dengan data hasil simulasi

\begin{tabular}{|c|c|c|c|c|}
\hline \multirow{2}{*}{ TIPE } & \multirow{2}{*}{ No } & \multirow{2}{*}{ DD/MM/YY } & \multicolumn{2}{|c|}{ ARAH DISPERSI } \\
\hline & & & DATA SATELIT & SIMULASI \\
\hline & 1 & 10/01/2004 & NNE & - \\
\hline $\mathbf{T}$ & 2 & $05 / 01 / 2005$ & NE & - \\
\hline $\mathbf{I}$ & 3 & $15 / 08 / 2005$ & SW & - \\
\hline $\mathbf{P}$ & 4 & 29/04/2006 & SW & SSW \\
\hline \multirow[t]{2}{*}{$\mathbf{E}$} & 5 & $24 / 06 / 2006$ & SSE & SSE \\
\hline & 6 & $09 / 01 / 2007$ & $E$ & ENE \\
\hline $\mathbf{B}$ & 7 & $18 / 05 / 2007$ & $\mathrm{~S}$ & SSE \\
\hline $\mathbf{E}$ & 8 & $22 / 09 / 2007$ & SSW & SW \\
\hline $\mathbf{L}$ & 9 & $06 / 07 / 2008$ & SSE & $\mathrm{S}$ \\
\hline \multirow[t]{3}{*}{$\mathbf{T}$} & 10 & $12 / 05 / 2011$ & SE & SSE \\
\hline & 11 & $02 / 12 / 2006$ & SSW & SW \\
\hline & No & DD/MM/YY & DATA SATELIT & SIMULASI \\
\hline \multirow{2}{*}{$\mathbf{T}$} & 1 & 20/08/2001 & ESE & - \\
\hline & 2 & $19 / 05 / 2002$ & NW & - \\
\hline $\mathbf{P}$ & 3 & $27 / 03 / 2004$ & WSW & - \\
\hline \multirow[t]{2}{*}{$\mathbf{E}$} & 4 & $25 / 06 / 2004$ & SSE & - \\
\hline & 5 & $30 / 05 / 2006$ & WSW & WSW \\
\hline \multirow{2}{*}{ L } & 6 & $15 / 06 / 2006$ & WSW & $w$ \\
\hline & 7 & $25 / 08 / 2006$ & $w$ & $w$ \\
\hline E & 8 & $05 / 10 / 2006$ & ESE & NE \\
\hline $\mathbf{A}$ & 9 & $06 / 08 / 2008$ & WSW & WSW \\
\hline $\mathbf{R}$ & 10 & $10 / 10 / 2008$ & Wrowad with & WNW \\
\hline
\end{tabular}




\begin{tabular}{|c|c|c|c|c|}
\hline & No & DD/MM/YY & DATA SATELIT & Simulasi \\
\hline \multirow{4}{*}{ T } & 1 & $30 / 11 / 2003$ & SW & - \\
\cline { 2 - 5 } & 2 & $22 / 05 / 2004$ & SW & - \\
\cline { 2 - 5 } I & 3 & $27 / 07 / 2004$ & SW & - \\
\cline { 2 - 5 } P & 4 & $27 / 05 / 2005$ & W & - \\
\cline { 2 - 5 } E & 5 & $18 / 02 / 2006$ & SE & - \\
\cline { 2 - 5 } & 6 & $03 / 10 / 2006$ & SSW & WSW \\
\cline { 2 - 5 } F & 7 & $27 / 03 / 2006$ & WNW & WSW \\
\cline { 2 - 5 } A & 8 & $03 / 08 / 2006$ & NNE & NE \\
\cline { 2 - 5 } N & 9 & $22 / 11 / 2006$ & WSW & SW \\
\cline { 2 - 5 } & 10 & $05 / 08 / 2007$ & SSW & SSW \\
\cline { 2 - 5 } & 11 & $24 / 08 / 2007$ & WSW & SW \\
\cline { 2 - 5 } & 12 & $26 / 08 / 2008$ & W & WSW \\
\cline { 2 - 5 } & 13 & $20 / 06 / 2008$ & NW & WNW \\
\hline
\end{tabular}

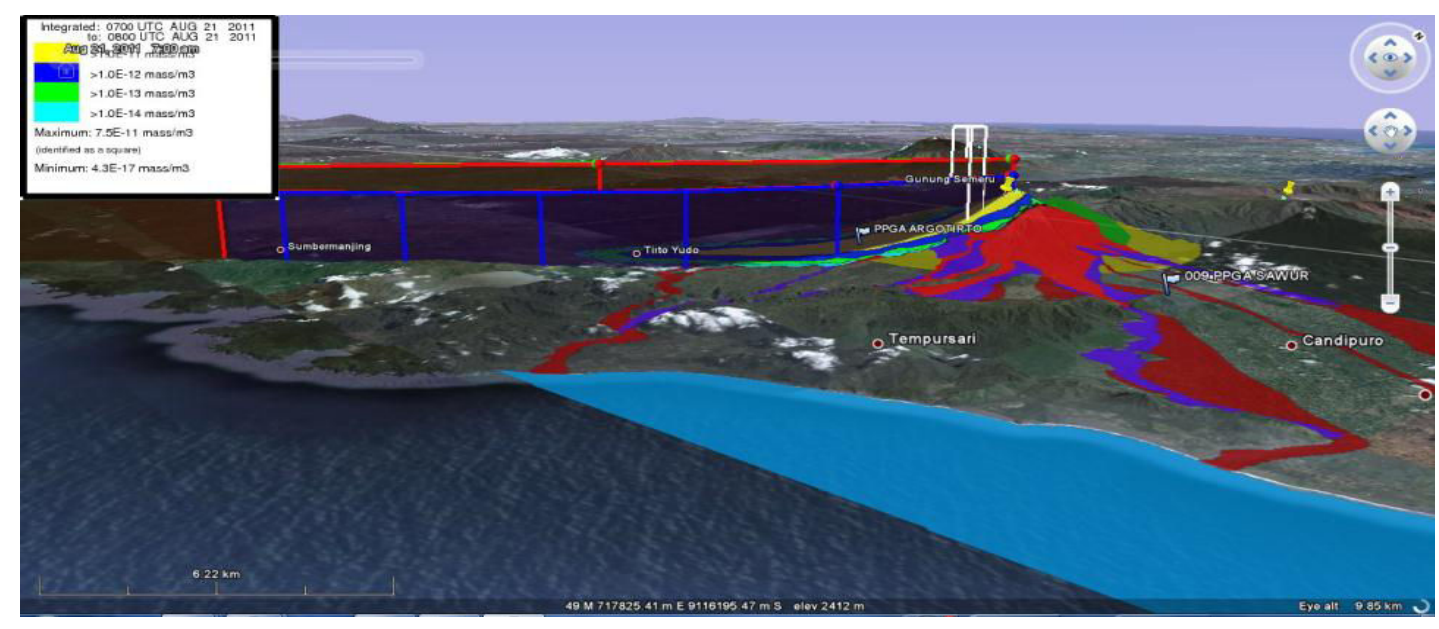

Gambar 10. Ketinggian Trajektori Awan debu vulkanik Gunung Semeru

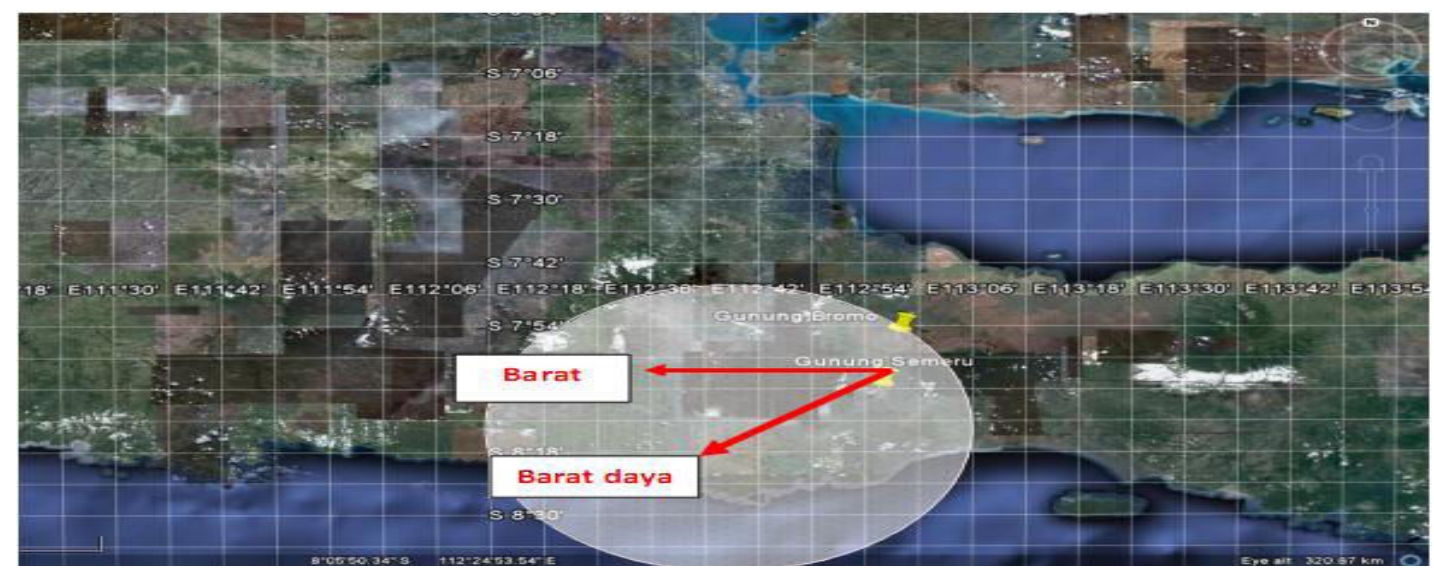

Gambar 11. Radius mitigasi dampak trajektori awan debu vulkanik Gunung Semeru 
Sedangkan arahan mitigasi bencana awan debu vulkanik didasarkan data citra satelit Landsat TM dan Citra Satelit CALIPSO serta simulasi ditunjukkan pada Gambar 10 dan Gambar 11 dengan radius pergerakan arah trajektori awan debu vulkanik antara $30 \mathrm{Km}$ sampai dengan $50 \mathrm{Km}$ dan pada ketinggian $3500 \mathrm{~m}$ samapi $6000 \mathrm{~m}$ diatas permukaan laut.

\section{KESIMPULAN}

Karakteristik awan debu vulkanik Gunung Semeru terdispersi ke arah Barat (West), Barat Barat Daya (West-South-West) dan Selatan (South) dengan radius antara $30 \mathrm{Km}$ sampai $50 \mathrm{Km}$ dari Gunung Semeru pada ketinggian antara $3500 \mathrm{~m}$ sampai dengan 6000 $\mathrm{m}$ atau 11.000 feet sampai dengan 25.000 feet dari permukaan laut. Kondisi tersebut menunjukkan bahwa dampak debu vulkanik Gunung Semeru lebih dominan bergerak dan jatuh di wilayah Kota Malang dan Kabupaten Malang kemudian diikuti wilayah Kabupaten Lumajang, Kabupaten Pasuran dan Kabupaten Probolinggo. Adapun arahan mitigasi bencana atau dampak awan debu vulkanik Gunung Semeru berada diwilayah tersebut diatas.

\section{DAFTAR PUSTAKA}

[1] Claire J. Horwell, 2007, Grain-Size Analysis Of Volcanic Ash For The Rapid Assessment Of Espiratory Health Hazard, Journal of Environmental Monitoring

[2] Draxler R.R, 1997, Description Of The Hysplit_4 Modeling System, Air Resources Laboratory Silver Spring, Maryland, 1997

[3] Heiken G dan Wohletz, K, 1992, Volcanic Ash, University Of California Press, Berkeley London.

[4] Kenneth S, Jiang Z, Peter W, dan Patrick C, 2007, Volcanic Ash Plume Identification Using Polarization Lidar: Augustine Eruption, Alaska, Geophysical Research Letters, VOL. 34, L08803, doi:10.1029/2006GL027237.

[5] Kinoshita K, Masumizu T, dan Tsutsumi K, 1992, Analysis of Satellite Image on The Dispersion of Volcanic Ash Clouds from Mt. Sakurajima, Proc. 18th Int. Symp. On Space Technology and Science, Kagoshima.

[6]Pavolonis, M.J.,2010. Advances in extracting cloud composition information from spaceborne infrared radiances: A robust alternative to brightness temperatures Part I: Theory, J.Applied Meteorol And Climatology, 49(9)

[7]Rose, W.I., Durant, A.J, 2009, Fine Ash Content Of Explosive Eruptions, Journal of Volcanology and Geothermal Research, doi:10.1016/j.jvolgeores.2009.01.010 